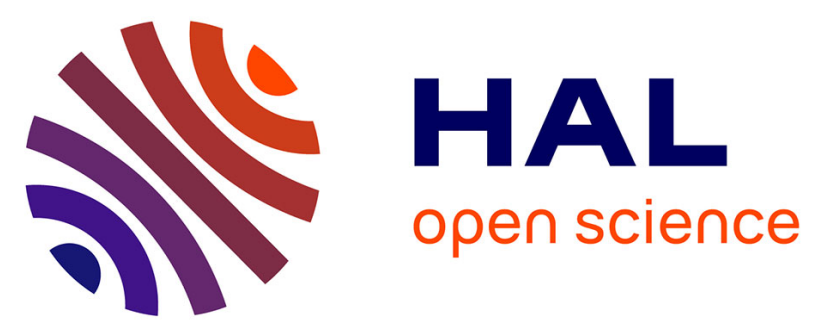

\title{
A DFT and experimental investigation of the electron affinity of the triscyclopentadienyl uranium complexes Cp3UX
}

\author{
Aziz Elkechai, Abdou Boucekkine, Lotfi Belkhiri, Mhand Amarouche, \\ Caroline Clappe, Didier Hauchard, Michel Ephritikhine
}

\section{To cite this version:}

Aziz Elkechai, Abdou Boucekkine, Lotfi Belkhiri, Mhand Amarouche, Caroline Clappe, et al.. A DFT and experimental investigation of the electron affinity of the triscyclopentadienyl uranium complexes Cp3UX. Journal- Chemical Society Dalton Transactions, 2009, 15, pp.2843-2849. 10.1039/b820873e . hal-00389602

\section{HAL Id: hal-00389602 https://hal.science/hal-00389602}

Submitted on 12 Sep 2013

HAL is a multi-disciplinary open access archive for the deposit and dissemination of scientific research documents, whether they are published or not. The documents may come from teaching and research institutions in France or abroad, or from public or private research centers.
L'archive ouverte pluridisciplinaire HAL, est destinée au dépôt et à la diffusion de documents scientifiques de niveau recherche, publiés ou non, émanant des établissements d'enseignement et de recherche français ou étrangers, des laboratoires publics ou privés. 


\title{
A DFT and experimental investigation of the electron affinity of the triscyclopentadienyl uranium complexes $\mathrm{Cp}_{3} \mathrm{UX} \dagger$
}

\author{
Aziz Elkechai, ${ }^{a, b}$ Abdou Boucekkine, ${ }^{* b, c}$ Lotfi Belkhiri, ${ }^{d}$ MHand Amarouche,${ }^{a}$ Caroline Clappe,${ }^{e}$ \\ Didier Hauchard $^{f, c}$ and Michel Ephritikhine ${ }^{g}$
}

\author{
Received 21st November 2008, Accepted 6th February 2009 \\ First published as an Advance Article on the web 26th February 2009 \\ DOI: 10.1039/b820873e
}

Relativistic Density Functional Theory (DFT) based methods coupled with the Conductor-like Screening Model (COSMO) for a realistic solvation approach are used to investigate the electron affinity (EA) of a series of triscyclopentadienyl uranium complexes $\mathrm{Cp}_{3} \mathrm{UX}\left(\mathrm{X}=\mathrm{Cl}, \mathrm{BH}_{4}, \mathrm{SPh}, \mathrm{S} \operatorname{Pr}\right.$ and $\mathrm{O}^{i} \mathrm{Pr}$ ) related to the $\mathrm{U}(\mathrm{IV}) / \mathrm{U}(\mathrm{III})$ redox system. $E_{1 / 2}$ half-wave potentials have been measured in solution (THF) under the same rigorous conditions for all the species under consideration. A good correlation $\left(r^{2}=0.99\right)$ is found between the computed EA values, either in the gas phase or in solution, and the experimental half-wave potentials; the study brings to light the importance of spin-orbit coupling effects which must be taken into account in order to achieve the observed agreement between theory and experiment. The influence of the electron donating character of the X ligand on the orbital involved in the reduction process, namely the lowest unoccupied molecular orbital (LUMO) of the neutral U(IV) complexes, and on the EAs is discussed.

\section{Introduction}

The electron affinity (EA) is an important property of atoms and molecules which was discussed in detail in a recent review. ${ }^{1}$ The EAs play a major role in many areas of pure chemistry, materials science and environmental chemistry, but their experimental measurement and/or theoretical determination is generally not easy. It was shown that photoelectron techniques are the most accurate and reliable experimental methods for measuring EAs, and that Density Functional Theory (DFT) is one of the most used computational methods in the case of large molecules permitting to achieve a satisfactory accuracy (within $0.2 \mathrm{eV}$ ). ${ }^{1}$

The molecular chemistry of uranium is currently witnessing an impressive development, together with the theoretical chemistry and solid-state chemistry of the f-block elements, revealing unsuspected structural and reactivity features. ${ }^{2}$ These advances are most spectacular in organo-uranium chemistry, where the proper choice of ligands permitted to synthesize a rich diversity of complexes in various oxidation states, with novel coordination

${ }^{a}$ Laboratoire de physique et chimie quantique, Faculté des sciences, Université Mouloud Mammeri de Tizi-Ouzou, 15000, Tizi-Ouzou, Algérie

${ }^{b}$ Laboratoire sciences chimiques de Rennes, UMR CNRS 6226, Université de Rennes 1, Campus de Beaulieu, 35042, Rennes Cedex, France. E-mail: abdou.boucekkine@univ-rennes1.fr

'Université européenne de Bretagne, 12 avenue Janvier, 35000 Rennes, France ${ }^{d}$ Laboratoire de chimie moléculaire (LACMOM), Faculté des sciences, Université Mentouri de Constantine, 25017, Constantine, Algérie

${ }^{e}$ Laboratoire de chimie et génie des procédés, Ecole centrale de Paris, Grande Voie des Vignes, 92295, Châtenay-Malabry Cedex, France

${ }^{f}$ Ecole Nationale Supérieure de Chimie de Rennes, CNRS, UMR 6226, Avenue du Général Leclerc, CS 50837, 35708, Rennes Cedex 7, France ${ }^{g}$ CEA, IRAMIS, Service de chimie moléculaire, CNRS URA 331, CEA/Saclay, 91191, Gif-sur-Yvette, France.E-mail: michel.ephritikhine@ cea.fr

$\dagger$ Electronic supplementary information (ESI) available: Optimized geometries and coordinates of $\mathrm{Cp}_{3} \mathrm{UX}$ complexes, and MO diagrams. See DOI: $10.1039 / \mathrm{b} 820873 \mathrm{e}$ geometry, and exhibiting interesting physico-chemical properties or catalytic activity. The cyclopentadienyl ligand has occupied a predominant place in this discipline from its beginning with the synthesis of the triscyclopentadienyl compounds $\mathrm{Cp}_{3} \mathrm{UCl}^{3}$ and $\mathrm{Cp}_{3} \mathrm{U}^{4}\left(\mathrm{Cp}=\mathrm{C}_{5} \mathrm{H}_{5}\right)$, the first organo-uranium(IV) and (III) complexes, isolated in 1956 and 1970, respectively. Some years later, the bispentamethylcyclopentadienyl compound $\mathrm{Cp}^{*}{ }_{2} \mathrm{UCl}_{2}$ $\left(\mathrm{Cp}^{*}=\mathrm{C}_{5} \mathrm{Me}_{5}\right)$ was found to be, as well as $\mathrm{Cp}_{3} \mathrm{UCl}$, the precursor of an important family of derivatives. ${ }^{5}$ The recent period is marked by the speeding up of emergence of new classes of organo-uranium compounds. Low-valent complexes, some of these appearing to have a much lower oxidation state than in reality, such as $\mathrm{Cp}_{2}{ }_{2} \mathrm{U}$ (terpy), ${ }^{6}$ show a fascinating reductive capacity, in particular in the activation of small molecules. The $\mathrm{U}(\mathrm{III})$ compound $\mathrm{Cp}_{3}{ }_{3} \mathrm{U}$, which was not expected to exist in view of its steric crowding, was found to react as a multiple electron reductant, undergoing the so-called sterically induced reduction, based on the fact that the cyclopentadienyl ligands are capable of reacting as reductants via the $\left(\mathrm{C}_{5} \mathrm{Me}_{5}\right)^{-} / \mathrm{C}_{5} \mathrm{Me}_{5}$ redox couple. ${ }^{7,8}$ The cyclopentadienyl ligand was also useful for the preparation of rare uranium compounds in the highest oxidation states, such as the $\mathrm{U}(\mathrm{v})$ complex $\mathrm{Cp}_{4}^{\prime} \mathrm{U}_{6} \mathrm{O}_{13}$ (bipy) ${ }_{2}\left(\mathrm{Cp}^{\prime}=1,2,4-{ }^{t} \mathrm{Bu}_{3} \mathrm{C}_{5} \mathrm{H}_{2}\right)^{9}$ and the $\mathrm{U}(\mathrm{VI})$ complexes $\mathrm{Cp}^{*}{ }_{2} \mathrm{U}(=\mathrm{NR})_{2}$ and $\left[\mathrm{Cp}^{*} \mathrm{UO}_{2}(\mathrm{CN})_{3}\right]\left[\mathrm{NEt}_{4}\right]_{2},{ }^{10,11}$ the latter being the first cyclopentadienyl complex of uranyl.

In view of the rich diversity of organo-uranium complexes, and the importance of the redox chemistry in understanding the reactivity trends, it seemed to us of interest to get access to the EAs of some representative compounds, especially those with the ubiquitous cyclopentadienyl ligand. To the best of our knowledge, there is only one theoretical investigation of the EAs of actinide compounds which concerns the fluoroketimide complexes $\mathrm{Cp}^{*}{ }_{2} \mathrm{U}(-\mathrm{N}=\mathrm{CMeR})_{2}\left(\mathrm{R}=4-\mathrm{F}-\mathrm{C}_{6} \mathrm{H}_{4}\right.$ or $\left.\mathrm{C}_{6} \mathrm{~F}_{5}\right),{ }^{12}$ while a relatively few voltammetry experiments on triscyclopentadienyl and bispentamethylcyclopentadienyl complexes led to the observation of the $\mathrm{U}(\mathrm{III}) / \mathrm{U}(\mathrm{IV}), \mathrm{U}(\mathrm{IV}) / \mathrm{U}(\mathrm{v})$ and $\mathrm{U}(\mathrm{v}) / \mathrm{U}(\mathrm{VI})$ redox systems, 
depending on the nature of the different ligand sets. ${ }^{12-20}$ Here we present relativistic DFT calculations of the EAs of $\mathrm{Cp}_{3} \mathrm{UX}$ $\left(\mathrm{X}=\mathrm{Cl}, \mathrm{BH}_{4}, \mathrm{SPh}, \mathrm{S}^{i} \mathrm{Pr}, \mathrm{O}^{i} \mathrm{Pr}\right.$ ) complexes. In order to compare computed EAs to electrochemical experimental data obtained in solution, solvent effects are taken into account using the Conductor-like Screening Model (COSMO) approach. ${ }^{21}$

Obviously, the present study will firstly check the accuracy of the used computational technique.

Our objectives were to analyze the influence of the different $\mathrm{X}$ ligands on the EAs and to find a correlation between the computed values of these EAs and experimental data given in the form of half-wave potentials, to reveal the role of involved orbitals, namely the lowest unoccupied molecular orbital (LUMO) of the neutral species in the redox process, and to rationalize the evolution of the property in the series of complexes under consideration.

\section{Results and discussion}

\section{Molecular geometry optimizations}

All geometries are fully optimized at the ZORA/BP86/TZP spin unrestricted level considering the highest spin state, i.e. triplet $\left(5 \mathrm{f}^{2}\right)$ and quartet state $\left(5 f^{\mathfrak{3}}\right)$ for the $\mathrm{U}(\mathrm{IV})$ and $\mathrm{U}(\mathrm{III})$ species respectively, first in the gas phase, and then in solution using the COSMO model (see Computational details). $\mathrm{Cp}_{3} \mathrm{UCl}$ and $\mathrm{Cp}_{3} \mathrm{U}\left(\eta^{3}-\mathrm{BH}_{4}\right)$ have been taken in the $C_{\mathrm{s}}$ symmetry whereas the three other species exhibit $C_{1}$ symmetry. In Table 1 are given the most relevant computed bond distances and angles for the U(III) and U(Iv) complexes in the gas phase as well as in solution (the optimized structures and coordinates are given in the $\mathrm{ESI} \dagger$ ).

We discuss first the gas phase geometries. The calculated geometrical parameters of $\mathrm{Cp}_{3} \mathrm{UCl}$ and $\mathrm{Cp}_{3} \mathrm{U}\left(\eta^{3}-\mathrm{BH}_{4}\right)$ are in good agreement with the experimental crystallographic data, in particular the U-Cl and U-B distances of 2.614 and $2.553 \AA$, which are slightly larger than those of $2.559(16)$ and $2.48 \AA$ determined by X-ray diffraction. ${ }^{22,23}$ The computed U-S distances of $\mathrm{Cp}_{3} \mathrm{USR}\left(\mathrm{R}=\mathrm{Ph},{ }^{i} \mathrm{Pr}\right), 2.714$ and $2.697 \AA$, and the U-O distance of $\mathrm{Cp}_{3} \mathrm{UO}^{i} \mathrm{Pr}, 2.082 \AA$, can be compared with those of 2.695(4),
2.135(8) and 2.119(7) $\AA$ in the crystal structures of $\mathrm{Cp}_{3} \mathrm{USMe},{ }^{24}$ $\mathrm{Cp}_{3} \mathrm{UOSiPh}_{3}{ }^{25}$ and $\mathrm{Cp}_{3} \mathrm{UOPh}{ }^{26}$ respectively. The $\mathrm{Cp}$ centroid$\mathrm{U}-\mathrm{Cp}$ centroid and $\mathrm{Cp}$ centroid-U-X angles in the U(III) and $\mathrm{U}(\mathrm{IV})$ compounds are also well reproduced, with typical values of $116^{\circ}$ and $100^{\circ}$, respectively. The U-X and average U-C distances are larger in the $\mathrm{U}(\mathrm{III})$ compound than in the $\mathrm{U}(\mathrm{IV})$ precursor, by $0.084-0.145$ and $0.025-0.044 \AA$ respectively, correlating with the increase of $0.160 \AA$ in the radii of the $\mathrm{U}^{3+}$ and $\mathrm{U}^{4+}$ ions. ${ }^{27}$ The lengthening of the $\mathrm{U}-\mathrm{S}$ and average $\mathrm{U}-\mathrm{C}$ distances from $\mathrm{Cp}_{3}$ USR to $\left[\mathrm{Cp}_{3} \mathrm{USR}^{-}\right.$can be compared with that of 0.145 and $0.080 \AA$ measured from the crystal structures of $\mathrm{Cp}^{*}{ }_{2} \mathrm{U}(\mathrm{SMe})_{2}{ }_{2}{ }^{28}$ and $\left[\mathrm{Cp}_{2}{ }_{2} \mathrm{U}\left(\mathrm{S}^{i} \mathrm{Pr}\right)_{2}\right]^{-}{ }^{-29} \mathrm{We}$ also note the very slight variation of the $\mathrm{Cp} \mathrm{C}-\mathrm{C}$ bond lengths when passing from the $\mathrm{U}(\mathrm{IV})$ to the $\mathrm{U}(\mathrm{III})$ species, which is indicative that the reduction process does not affect the $\mathrm{Cp}$ ring.

As it can be seen in Table 1, the influence of the solvent on bond lengths and bond angles is rather small except for the $\mathrm{U}-\mathrm{X}$ distance which undergoes a small variation (less than 1-2\%). Interestingly we note that the $\mathrm{U}-\mathrm{O} i \operatorname{Pr}$ bond length decreases in the solvent whereas the other $\mathrm{U}-\mathrm{X}$ distances increase.

\section{Electron affinities (EAs)}

In all cases, the EAs were calculated as differences of the energies of the neutral U(IV) and anionic U(III) species at their optimized geometries. In terms of the Total Binding Energy (TBE) computed by ADF, EAs are computed as follows:

$$
\begin{gathered}
\mathrm{EA}=\Delta E=\mathrm{TBE}(\text { optimized } \mathrm{U}(\mathrm{IV}) \text { complex })-\mathrm{TBE}(\text { optimized } \\
\mathrm{U}(\mathrm{III}) \text { complex }) .
\end{gathered}
$$

In Tables 2 and 3 are given the TBEs and EAs of the $\mathrm{Cp}_{3} \mathrm{UX}$ complexes as obtained at the ZORA/BP86/TZP level of theory; the more extended TZ2P basis set led us to quite similar values of the EAs. In these tables, TBE(so) and EA(so) are the values including the spin-orbit correction whereas $\mathrm{TBE}(\mathrm{THF}+\mathrm{so})$ and $\mathrm{EA}(\mathrm{THF}+\mathrm{so})$ include the solvent effect and spin-orbit correction. In the last column of Table 3 are displayed the measured

Table 1 Relevant computed distances $(\AA)$ and angles $\left(^{\circ}\right)$ of the $\mathrm{Cp}_{3} \mathrm{UX} /\left[\mathrm{Cp}_{3} \mathrm{UX}\right]^{-}$complexes (COSMO values in brackets and X-ray ones in square

\begin{tabular}{|c|c|c|c|c|c|}
\hline $\mathrm{X}$ & $\mathrm{Cl}$ & $\mathrm{BH}_{4}$ & $\mathrm{SPh}$ & $\mathrm{S}^{i} \mathrm{Pr}$ & $\mathrm{O}^{i} \mathrm{Pr}$ \\
\hline \multicolumn{6}{|l|}{$<\mathrm{C}-\mathrm{C}>$} \\
\hline Gas phase & $1.415 / 1.410$ & $1.421 / 1.425$ & $1.421 / 1.422$ & $1.420 / 1.422$ & $1.420 / 1.423$ \\
\hline $\begin{array}{l}\text { Solution } \\
<\mathrm{U}-\mathrm{C}>\end{array}$ & $(1.421 / 1.425)$ & $(1.420 / 1.421)$ & $(1.421 / 1.423)$ & $(1.421 / 1.423)$ & $(1.421 / 1.422)$ \\
\hline Gas phase & $2.774 / 2.810$ & $2.782 / 2.836$ & $2.776 / 2.806$ & $2.778 / 2.812$ & $2.788 / 2.823$ \\
\hline Solution & $(2.770 / 2.795)$ & $(2.785 / 2.843)$ & $(2.768 / 2.804)$ & $(2.778 / 2.823)$ & $(2.793 / 2.820)$ \\
\hline X-Ray & {$[2.740]$} & - & - & - & - \\
\hline \multicolumn{6}{|l|}{$\mathrm{U}-\mathrm{X}$} \\
\hline Gas phase & $2.614 / 2.725$ & $2.533 / 2.640$ & $2.714 / 2.849$ & $2.697 / 2.842$ & $2.082 / 2.166$ \\
\hline Solution & $(2.654 / 2.793)$ & $(2.557 / 2.685)$ & $(2.739 / 2.850)$ & $(2.703 / 2.845)$ & $(2.065 / 2.136)$ \\
\hline X-Ray & {$[2.559]$} & {$[2.48]$} & - & - & - \\
\hline \multicolumn{6}{|l|}{$<\mathrm{Cp}-\mathrm{U}-\mathrm{Cp}>$} \\
\hline Gas phase & $117.0 / 116.4$ & $115.5 / 114.7$ & $116.8 / 116.5$ & $116.5 / 115.6$ & $116.6 / 116.8$ \\
\hline Solution & $(116.9 / 116.3)$ & $(115.3 / 115.3)$ & $(116.5 / 116.7)$ & $(116.5 / 115.5)$ & $(116.3 / 116.0)$ \\
\hline X-Ray & {$[116.7]$} & - & - & - & - \\
\hline \multicolumn{6}{|l|}{$<\mathrm{Cp}-\mathrm{U}-\mathrm{X}>$} \\
\hline Gas phase & $100.1 / 101.0$ & $102.4 / 103.5$ & $100.1 / 101.0$ & $101.1 / 102.5$ & 101.3/101.7 \\
\hline Solution & $(100.2 / 100.8)$ & $(102.5 / 102.5)$ & $(100.7 / 100.9)$ & $(100.8 / 102.2)$ & $(101.2 / 101.6)$ \\
\hline X-Ray & {$[101.0]$} & - & - & - & - \\
\hline
\end{tabular}
brackets) 
Table 2 Calculated TBEs of neutral U(IV) and anionic U(III) complexes

\begin{tabular}{|c|c|c|c|c|c|c|}
\hline Complex & $\mathrm{TBE} \mathrm{U}(\mathrm{III}) / \mathrm{eV}$ & $\mathrm{TBE}$ (so) $\mathrm{U}(\mathrm{III}) / \mathrm{eV}$ & $\mathrm{TBE}(\mathrm{THF}+\mathrm{so}) \mathrm{U}(\mathrm{III}) / \mathrm{eV}$ & TBE U(IV)/eV & $\mathrm{TBE}$ (so) $\mathrm{U}(\mathrm{IV}) / \mathrm{eV}$ & $\mathrm{TBE}(\mathrm{THF}+\mathrm{so}) \mathrm{U}(\mathrm{IV}) / \mathrm{eV}$ \\
\hline $\mathrm{Cp}_{3} \mathrm{UCl}$ & -201.012 & -203.524 & -205.466 & -199.607 & -201.722 & -201.829 \\
\hline $\mathrm{Cp}_{3} \mathrm{U}(\mathrm{SPh})$ & -272.481 & -274.966 & -276.827 & -270.977 & -273.244 & -273.296 \\
\hline $\mathrm{Cp}_{3} \mathrm{U}\left(\mathrm{BH}_{4}\right)$ & -217.837 & -220.355 & -221.348 & -216.546 & -218.744 & -218.227 \\
\hline $\mathrm{Cp}_{3} \mathrm{U}\left(\mathrm{S}^{i} \mathrm{Pr}\right)$ & -253.558 & -256.025 & -257.135 & -252.249 & -254.454 & -254.462 \\
\hline $\mathrm{Cp}_{3} \mathrm{U}\left(\mathrm{O}^{i} \mathrm{Pr}\right)$ & -256.692 & -259.105 & -259.063 & -255.761 & -257.987 & -257.995 \\
\hline
\end{tabular}

Table 3 Calculated EAs of neutral U(IV) and anionic U(III) complexes

\begin{tabular}{lllll}
\hline Complex & EA/eV & EA(so)/eV & EA(THF + so $) / e V$ & $-E_{1 / 2} / \mathrm{V}$ \\
\hline $\mathrm{Cp}_{3} \mathrm{UCl}$ & 1.405 & 1.802 & 3.637 & 1.875 \\
$\mathrm{Cp} \mathrm{p}_{3} \mathrm{U}(\mathrm{SPh})$ & 1.504 & 1.722 & 3.531 & 1.900 \\
$\mathrm{Cp}_{3} \mathrm{U}\left(\mathrm{BH}_{4}\right)$ & 1.291 & 1.611 & 3.121 & 1.995 \\
$\mathrm{Cp}_{3} \mathrm{U}\left(\mathrm{S}^{i} \mathrm{Pr}\right)$ & 1.309 & 1.571 & 2.673 & 2.026 \\
$\mathrm{C} \mathrm{p}_{3} \mathrm{U}\left(\mathrm{O}^{i} \mathrm{Pr}\right)$ & 0.931 & 1.118 & 1.068 & 2.385 \\
\hline
\end{tabular}

half-wave reduction potentials $\left(-E_{1 / 2} v s .\left[\mathrm{Cp}_{2} \mathrm{Fe}\right]^{+/ 0}\right)$ of the neutral uranium(IV) compounds (see the Experimental section).

Considering first the TBE and TBE(so) values, it can be seen that spin-orbit corrections lead to a non-negligible energy lowering of the order of $2.5 \mathrm{eV}$ for the $\mathrm{U}(\mathrm{III})$ species in their quartet state and $2.2 \mathrm{eV}$ for the U(IV) ones in their triplet states. All the computed $\mathrm{EA}(\mathrm{so})$ are positive, equal to $c a .1 .1-1.8 \mathrm{eV}$, the anionic $\mathrm{U}(\mathrm{III})$ complexes being calculated to be more stable than their $\mathrm{U}(\mathrm{IV})$ neutral precursors. We also note that the alkoxide derivative, $\mathrm{Cp}_{3} \mathrm{UO}^{i} \mathrm{Pr}$, which has the lowest half-wave reduction potential $(-2.385 \mathrm{~V})$ and is therefore the most difficult to reduce, also exhibits the lowest EA(so) $(1.118 \mathrm{eV})$ whereas the chloride congener $\mathrm{Cp}_{3} \mathrm{UCl}$ exhibits the highest one.

In order to compare computed EAs to experimental half-wave reduction potentials measured in solution, solvent effects must be taken into account.

Considering $\mathrm{TBE}(\mathrm{THF}+\mathrm{so})$ we note that, as expected, the solvent corrections are non-negligible especially for the anionic species, so that the EAs undergo an important variation. However, it is worth noting that the ordering of the reduction ability of the U(Iv) complexes under consideration is the same considering $\mathrm{EA}(\mathrm{so})$ or $\mathrm{EA}(\mathrm{THF}+\mathrm{so})$.

A good linear correlation appears between the computed $\mathrm{EA}(\mathrm{THF}+\mathrm{so})$ and measured $-E_{1 / 2}$, with the $r^{2}$ factor of the regression being equal to 0.99 (Fig. 1). The slope of the line is equal to -0.19 . This good agreement brings to light the reliability of DFT based methods coupled to the COSMO approach to study such reduction processes in solution.

It is interesting to note that the gas phase EA(so) also correlates very well with the experimental half-wave potential $\left(r^{2}=0.99\right)$. Thus, it appears that in our case, solvation affects similarly

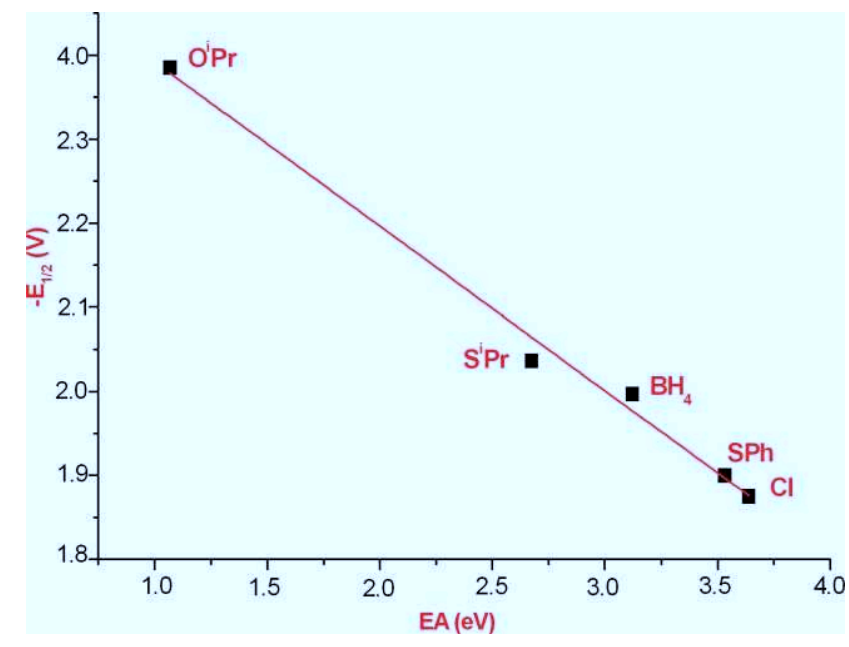

Fig. 1 Experimental $-E_{1 / 2}$ vs. computed EAs.

the energy differences of the $\mathrm{U}(\mathrm{IV})$ and $\mathrm{U}(\mathrm{III})$ species under consideration.

We noticed that the neglect of the spin-orbit correction leads to a worsening of the $\mathrm{EA}(\mathrm{THF}+\mathrm{so}) v s$. $E_{1 / 2}$ correlation, i.e. the $r^{2}$ coefficient passes from the value 0.99 to 0.96 .

It is quite obvious that the variation of EAs are likely be related to the electron donating ability of the $\mathrm{X}$ ligand; one expects that a more donating ligand will lead to a complex exhibiting a smaller electron affinity. Indeed, the donating power of this ligand, as given by Hammett constants, leads to the following order: $\mathrm{Cl}<\mathrm{BH}_{4}<\mathrm{SPh}<\mathrm{S}^{i} \mathrm{Pr}<\mathrm{O}^{i} \mathrm{Pr}$ which suits well with the EAs variation (Table 3).

Our results are similar to those obtained by Kiplinger et al. who studied the fluoroketimide complexes $\mathrm{Cp}^{*}{ }_{2} \mathrm{U}(-\mathrm{N}=\mathrm{CMeR})_{2}{ }^{12 b}$ Using scalar relativistic DFT calculations at the B3LYP level, they obtained adiabatic EAs equal to $0.95 \mathrm{eV}$ and $1.24 \mathrm{eV}$ for $\mathrm{R}=4$ F- $\mathrm{C}_{6} \mathrm{H}_{4}$ and $\mathrm{R}=\mathrm{C}_{6} \mathrm{~F}_{5}$, respectively, whereas the corresponding $E_{1 / 2}$ are -2.64 and $-2.34 \mathrm{~V}$, showing that the complex exhibiting the highest EA is the easiest to reduce, in line with the greater electron-withdrawing property of the pentafluorophenyl group. ${ }^{12 b}$

In Table 4 are listed the energies, as computed by including, or not including, spin-orbit coupling and solvent effects, of the

Table 4 Calculated frontier MO energies

\begin{tabular}{|c|c|c|c|c|c|c|}
\hline Complex & SOMO U(III)/eV & $\mathrm{SOMO}($ so) U(III)/eV & $\begin{array}{l}\text { SOMO(THF+so) } \\
\text { U(III)/eV }\end{array}$ & LUMO U(IV)/eV & $\mathrm{LUMO}$ (so) U(IV)/eV & $\begin{array}{l}\mathrm{LUMO}(\mathrm{THF}+\mathrm{so}) \\
\mathrm{U}(\mathrm{IV}) / \mathrm{eV}\end{array}$ \\
\hline $\mathrm{Cp}_{3} \mathrm{UCl}$ & 1.226 & 1.086 & -1.889 & -3.615 & -3.632 & -3.636 \\
\hline $\mathrm{Cp}_{3} \mathrm{U}(\mathrm{SPh})$ & 1.028 & 0.885 & -1.774 & -3.501 & -3.527 & -3.572 \\
\hline $\mathrm{Cp}_{3} \mathrm{U}\left(\mathrm{BH}_{4}\right)$ & 1.252 & 1.052 & -1.752 & -3.541 & -3.558 & -3.552 \\
\hline $\mathrm{Cp}_{3} \mathrm{U}\left(\mathrm{S}^{i} \mathrm{Pr}\right)$ & 1.227 & 1.096 & -1.784 & -3.383 & -3.372 & -3.377 \\
\hline $\mathrm{Cp}_{3} \mathrm{U}\left(\mathrm{O}^{i} \mathrm{Pr}\right)$ & 1.624 & 1.559 & -1.297 & -3.018 & -2.977 & -2.979 \\
\hline
\end{tabular}


SOMOs of the U(III) complexes and of the LUMOs of the U(IV) ones. The LUMO energies of the neutral U(Iv) complexes are negative; this is indicative of the ability of these species to undergo a reduction process.

As it can be seen, the SOMO energies of the U(III) are positive; this was expected since these U(III) species are anions. This is not indicative of a spontaneous loss of an electron by these species because their MOs are definitively stabilized by their environment. In our case, these SOMOs are drastically stabilized in the THF solvent, their energies becoming negative.

The effect of spin-orbit coupling is more important on the MO energies of the U(III) complex in its quartet state than on those of the U(IV) complex in its triplet state. We also note that the variation of $\mathrm{LUMO}(\mathrm{THF}+\mathrm{so})$ energies is well consistent with that of $\mathrm{EA}(\mathrm{THF}+\mathrm{so})$, the lowest $\mathrm{LUMO}(\mathrm{THF}+\mathrm{so})$ corresponding to the highest $\mathrm{EA}(\mathrm{THF}+\mathrm{so})$. Moreover, considering the electron donation ability of the $\mathrm{X}$ ligand $\left(\mathrm{Cl}<\mathrm{BH}_{4}<\mathrm{SPh}<\mathrm{S}^{i} \mathrm{Pr}<\mathrm{O}^{i} \mathrm{Pr}\right)$, a rather good correlation is obtained between the LUMO energy of the U(IV) species and this property. Indeed, the $\mathrm{O}^{i} \mathrm{Pr}$ complex being the strongest electron donor and then experimentally the most difficult to reduce, exhibits the highest LUMO energy. A linear correlation is found between the experimental $-E_{1 / 2}$ values and the calculated LUMO(THF+so) energies $\left(r^{2}=0.95\right)$. This correlation is less satisfying than that obtained with EAs, because the LUMO energies are simply those of the neutral U(IV) species whereas the computed EAs take into account both electron and nuclear relaxation during the reduction process.
In Fig. 2 are displayed three frontier MOs of the U(Iv) complexes, i.e. the two SOMOs bearing each a single electron and the empty LUMO. The percentages $6 \mathrm{~d} / 5 \mathrm{f} / \mathrm{U} / \mathrm{X}$ indicate the weights of the $6 \mathrm{~d}$ and $5 \mathrm{f}$ metal orbitals as well as those of uranium and $\mathrm{X}$ ligand in the MOs (full frontier MO diagrams of the U(IV) complexes are given in the ESI $\dagger$ ).

It can be seen that these frontier MOs are mainly uranium $5 \mathrm{f}$ orbitals. The $\mathrm{X}$ contribution to the LUMO is zero, but it is interesting to note that the contribution of $\mathrm{Cp}_{3}{ }^{3-}$, computed as the difference $100 \%-\% \mathrm{U}$, is slightly higher for $\mathrm{Cp}_{3} \mathrm{UO}^{i} \mathrm{Pr}$ than for the other species, i.e. $8.8 \%$ vs. $5.6 \%$ for $\mathrm{Cp}_{3} \mathrm{UCl}$. As already seen (Table 3) this MO diagram shows that the LUMO energies follow the order: $\mathrm{Cl}<\mathrm{BH}_{4}<\mathrm{SPh}<\mathrm{S}^{i} \mathrm{Pr}<\mathrm{O}^{i} \mathrm{Pr}$, in accordance with the electron donating capacity of $\mathrm{X}$.

The Mulliken Population Analysis (MPA) given in Tables 5 and 6 brings to light some other aspects of the $\mathrm{U}-\mathrm{X}$ interaction. Although not very accurate, this population analysis may indicate roughly the major charge transfers and bonding interactions occurring in a molecule.

In these tables, $\mathrm{Q}$ and $\mathrm{T}$ indicate respectively the anionic $\mathrm{U}(\mathrm{III})$ and the neutral $\mathrm{U}(\mathrm{IV})$ species. Also given in Table 6 are the results of the Mayer analysis ${ }^{30}$ which provides atom-atom bond orders which have been shown to be useful tools in inorganic chemistry. ${ }^{31}$ All the given populations are the sum of the $\alpha$ and $\beta$ spin contributions.

Metal spin density is the difference between the total $\alpha$ and $\beta$ electronic populations of the metal; it appears to be lower than the total number of $5 \mathrm{f}$ electrons in the case of $\mathrm{U}(\mathrm{III})$ species but

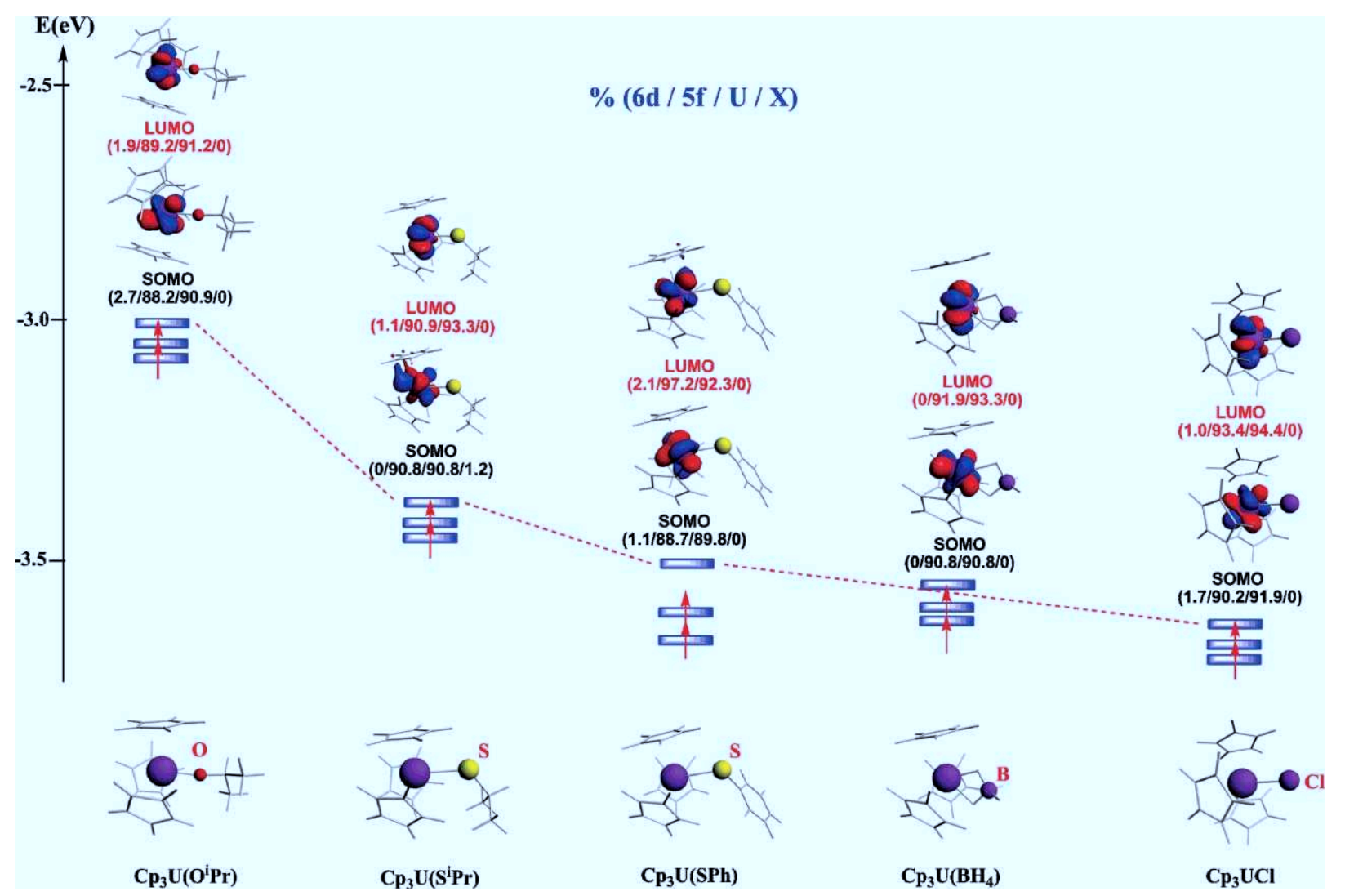

Fig. 2 Frontier MO diagrams of the U(IV) complexes. 
Table 5 Mulliken Population Analysis of the $\mathrm{Cp}_{3} \mathrm{UX} /\left[\mathrm{Cp}_{3} \mathrm{UX}\right]^{-}$complexes

\begin{tabular}{|c|c|c|c|c|c|c|c|c|c|}
\hline \multirow[b]{2}{*}{$\mathrm{Cp}_{3} \mathrm{U}-\mathrm{X}$} & \multirow[b]{2}{*}{ Spin state } & \multirow[b]{2}{*}{ Metal spin density } & \multicolumn{3}{|c|}{$\begin{array}{l}\text { Isolated molecule net } \\
\text { charges }\end{array}$} & \multicolumn{4}{|l|}{ Solvated molecule } \\
\hline & & & $\mathrm{U}^{q}$ & $\mathrm{Cp}_{3}{ }^{3-}$ & $\mathrm{X}^{-}$ & Metal spin density & $\mathrm{U}^{\mathrm{q}}$ & $\mathrm{Cp}_{3}{ }^{3-}$ & $\mathrm{X}^{-}$ \\
\hline \multirow[t]{2}{*}{$\mathrm{Cp}_{3} \mathrm{U}-\mathrm{Cl}$} & Q & 2.90 & +0.95 & -1.38 & -0.56 & 2.91 & +0.90 & -1.24 & -0.66 \\
\hline & $\mathrm{T}$ & 2.18 & +0.79 & -0.38 & -0.41 & 2.20 & +0.78 & -0.28 & -0.50 \\
\hline \multirow[t]{2}{*}{$\mathrm{Cp}_{3} \mathrm{U}-\mathrm{BH}_{4}$} & $\mathrm{Q}$ & 2.93 & +0.82 & -1.48 & -0.35 & 2.95 & +0.69 & -1.19 & -0.49 \\
\hline & $\mathrm{T}$ & 2.19 & +0.61 & -0.34 & -0.26 & 2.22 & +0.56 & -0.27 & -0.29 \\
\hline \multirow[t]{2}{*}{$\mathrm{Cp}_{3} \mathrm{U}-\mathrm{SPh}$} & $\mathrm{Q}$ & 2.93 & +0.83 & -1.29 & -0.53 & 2.93 & +0.79 & -1.26 & -0.53 \\
\hline & $\mathrm{T}$ & 2.22 & +0.65 & -0.36 & -0.29 & 2.22 & +0.59 & -0.26 & -0.34 \\
\hline \multirow[t]{2}{*}{$\mathrm{Cp}_{3} \mathrm{U}-\mathrm{S}^{i} \mathrm{Pr}$} & $\mathrm{Q}$ & 2.92 & +0.74 & -1.33 & -0.41 & 2.92 & +0.65 & -1.27 & -0.38 \\
\hline & $\mathrm{T}$ & 2.22 & +0.65 & -0.39 & -0.27 & 2.22 & +0.49 & -0.22 & -0.26 \\
\hline \multirow[t]{2}{*}{$\mathrm{Cp}_{3} \mathrm{U}-\mathrm{O}^{i} \mathrm{Pr}$} & Q & 2.91 & +1.17 & -1.61 & -0.56 & 2.88 & +1.14 & -1.72 & -0.41 \\
\hline & $\mathrm{T}$ & 2.17 & +1.04 & -0.62 & -0.42 & 2.18 & +1.01 & -0.78 & -0.23 \\
\hline
\end{tabular}

Table 6 Mulliken overlap populations and Mayer bond orders of the $\mathrm{Cp}_{3} \mathrm{UX} /\left[\mathrm{Cp}_{3} \mathrm{UX}\right]^{-}$complexes

\begin{tabular}{|c|c|c|c|c|c|}
\hline \multirow[b]{3}{*}{$\mathrm{Cp}_{3} \mathrm{U}-\mathrm{X}$} & \multirow[b]{3}{*}{ Spin state } & \multirow{2}{*}{\multicolumn{2}{|c|}{$\begin{array}{l}\text { MPA atom-atom } \\
\text { overlap } \\
\text { population }\end{array}$}} & \multicolumn{2}{|c|}{$\begin{array}{l}\text { U-X Mayer bond } \\
\text { order }\end{array}$} \\
\hline & & & & \multirow{2}{*}{$\begin{array}{l}\text { Isolated } \\
\text { molecule }\end{array}$} & \multirow{2}{*}{$\begin{array}{l}\text { Solvated } \\
\text { molecule }\end{array}$} \\
\hline & & $\mathrm{U}-\mathrm{Cp}_{3}{ }^{a}$ & $\mathrm{U}-\mathrm{X}$ & & \\
\hline \multirow[t]{2}{*}{$\mathrm{Cp}_{3} \mathrm{U}-\mathrm{Cl}$} & $\mathrm{Q}$ & 0.598 & 0.098 & 0.763 & 0.603 \\
\hline & $\mathrm{T}$ & 0.693 & 0.134 & 0.850 & 0.744 \\
\hline \multirow[t]{2}{*}{$\mathrm{Cp}_{3} \mathrm{U}-\mathrm{BH}_{4}{ }^{b}$} & Q & 0.520 & 0.044 & 0.587 & 0.510 \\
\hline & $\mathrm{T}$ & 0.582 & 0.052 & 0.878 & 0.654 \\
\hline \multirow{2}{*}{$\mathrm{Cp}_{3} \mathrm{U}-\mathrm{SPh}$} & $\mathrm{Q}$ & 0.540 & 0.174 & 0.761 & 0.687 \\
\hline & $\mathrm{T}$ & 0.624 & 0.196 & 0.987 & 0.933 \\
\hline \multirow[t]{2}{*}{$\mathrm{Cp}_{3} \mathrm{U}-\mathrm{S}^{i} \mathrm{Pr}$} & $\mathrm{Q}$ & 0.574 & 0.200 & 0.865 & 0.745 \\
\hline & $\mathrm{T}$ & 0.641 & 0.226 & 1.112 & 1.056 \\
\hline \multirow[t]{2}{*}{$\mathrm{Cp}_{3} \mathrm{U}-\mathrm{O}^{i} \mathrm{Pr}$} & $\mathrm{Q}$ & 0.570 & 0.231 & 0.762 & 0.841 \\
\hline & $\mathrm{T}$ & 0.646 & 0.234 & 0.988 & 0.993 \\
\hline
\end{tabular}

${ }^{a}$ Sum of the three $\mathrm{U}-\mathrm{Cp}$ contributions. ${ }^{b} \mathrm{U}-\mathrm{BH}_{4}$ populations and bond orders are the sum of the contributions of the three $\mathrm{U}-\mathrm{H}$ bonds of the $\mathrm{U}-\left(\eta^{3}-\mathrm{H}_{3}\right)$ coordination.

higher than the number of $5 \mathrm{f}$ electrons of the U(IV) complexes. For instance, the MPA metal spin density is equal to 2.90 instead of 3 for the $\left[\mathrm{Cp}_{3} \mathrm{UCl}\right]^{-}$anion, while it is 2.18 instead of 2 for the neutral U(IV) complex. In each case a small delocalization of electron spin on the ligands occurs. Similar metal spin densities have been obtained by comparing the U(III) and U(IV) $\mathrm{Cp}^{*}{ }_{2} \mathrm{U}(-\mathrm{N}=\mathrm{CMeR})_{2}$ fluoroketimide uranium complexes. ${ }^{12 b}$

Donation is well demonstrated by the net charge of the metal which is much lower than its oxidation state, but it must be pointed out that MPA generally overestimates this ligand-to-metal donation. Ligand-to-metal donation is also demonstrated by the weak negative charges of $\mathrm{Cp}_{3}{ }^{(3-)}$ and $\mathrm{X}^{(-)}$. Note that in Table 5 the displayed $\mathrm{X}$ net charge is that of the $\mathrm{X}$ group as a whole and not only of the atom linked to uranium, and that the charge of the $\mathrm{Cp}_{3}{ }^{(3-)}$ moiety is the sum of the charges of the three Cp's.

Moreover, considering the neutral U(IV) complexes, except the $\mathrm{X}=\mathrm{O}^{i} \mathrm{Pr}$ case, it can be seen that the $\mathrm{U}$ positive net charge diminishes when the donating strength of $\mathrm{X}$ increases. However, we note that in our case, the most donating group $\mathrm{X}=\mathrm{O}^{i} \mathrm{Pr}$ does not lead to the lowest net charge of the central metal. Nevertheless, we find a good correlation between the uranium U(IV) net charges and EAs or $E_{1 / 2}\left(r^{2}=0.95\right.$ and 0.96 respectively, removing $\mathrm{X}=\mathrm{O}^{i} \mathrm{Pr}$ ).

As it can be seen in Table 5, solvation generally leads to a small variation of MPA net charges, whereas metal spin densities remains practically unchanged.

Except for the $\mathrm{Cp}_{3} \mathrm{UBH}_{4}$ complex which exhibits a $\mathrm{U}-\left(\eta^{3}-\mathrm{H}_{3}\right)$ coordination, the MPA overlap populations of the U(IV)-X bonds vary according to the order: $\mathrm{Cl}<\mathrm{SPh}<\mathrm{S}^{i} \mathrm{Pr}<\mathrm{O}^{i} \mathrm{Pr}$. Complexes with $\mathrm{O}^{i} \mathrm{Pr}$ and $\mathrm{S}^{i} \mathrm{Pr}$ exhibit a stronger $\mathrm{U}-\mathrm{X}$ covalent interaction reinforced by the more important electron donating character of the alkyl group. Except for $\mathrm{X}=\mathrm{O}^{i} \mathrm{Pr}$ which deviates from this correlation, Mayer bond orders follow the same order. Finally, the covalent character of the $\mathrm{U}-\mathrm{X}$ bond decreases with the oxidation state of uranium as it passes from +4 to +3 . We note that the solvent leads to a decrease of the Mayer bond order for all complexes except for $\mathrm{Cp}_{3} \mathrm{UO}^{i} \mathrm{Pr}$ in agreement with the variation of the bond length due to this solvent as obtained by the COSMO model (Table 1).

\section{Conclusions}

This work allowed for the first time to compute the electron affinities of several triscyclopentadienyl uranium complexes for which such theoretical data were not available. For our part, we made use of relativistic DFT including spin-orbit coupling. Solvent effects have been taken into account using the COSMO approach. A very good correlation $\left(r^{2}=0.99\right)$ between our computed EAs and experimental half-wave potentials $E_{1 / 2}$ for a series of $\mathrm{Cp}_{3} \mathrm{UX}$ complexes has been found. Our study brought to light the importance of spin-orbit coupling in order to achieve the obtained agreement between theory and experiment. Moreover, MO diagrams and population analyses permitted to understand the evolution of EA with the nature of the X ligand, especially with its electron donating capacity. Indeed, the electron affinities as well as the LUMO energies decrease with the electron-donating strength of $\mathrm{X}$ according to $\mathrm{Cl}<\mathrm{BH}_{4}<\mathrm{SPh}<\mathrm{S}^{i} \mathrm{Pr}<\mathrm{O}^{i} \mathrm{Pr}$. 


\section{Experimental}

\section{Electrochemical study}

Reagents. Air-sensitive complexes were handled with the rigorous exclusion of oxygen and moisture in Schlenk-type glassware. The complexes $\mathrm{Cp}_{3} \mathrm{UCl},{ }^{3} \mathrm{Cp}_{3} \mathrm{UBH}_{4},{ }^{32} \mathrm{Cp}_{3} \mathrm{USPh}^{24} \mathrm{Cp}_{3} \mathrm{US}^{i} \operatorname{Pr}^{24}$ and $\mathrm{Cp}_{3} \mathrm{UO}^{i} \operatorname{Pr}^{33}$ were prepared according to the published procedures.

Tetrahydrofuran (Aldrich) was stored under vacuum over sodium and benzophenone and transferred directly into the electrochemical cell by simple condensation (static vacuum method). Tetrabutylammonium hexafluorophosphate (Fluka, electrochemical grade), used without further purification, was dried under vacuum.

Electrochemical measurements. Electrochemical experiments were performed in a single-compartment three-electrode cell designed for highly air-sensitive compounds and connected to an argon-vacuum line.

The working electrodes were a platinum conventional disc electrode Radiometer Analytical Pt30 (0.5 mm radius) and a platinum disc microelectrode Radiometer Analytical MEPT (7.5 $\mu \mathrm{m}$ radius). The auxiliary electrode was a platinum wire Radiometer Analytical Pt11.

The reference electrode was a wire $\mathrm{Ag} / \mathrm{AgCl}$ in $\mathrm{THF}+\mathrm{Bu}_{4} \mathrm{NPF}_{6}$ (Radiometer Analytical RDJ 10). The ferricinium/ferrocene $\left(\left[\mathrm{Cp}_{2} \mathrm{Fe}\right]^{+/ 0}\right)$ system was used as an internal standard reference. All potentials are referenced to this couple.

Electrochemical measurements were carried out with EG \& G Princeton Applied Research potentiostat/galvanostat model 273 A controlled by a computer. In cyclic voltammetry, $i R$ drop was compensated by feedback method.

The electrochemical behaviour of the $\mathrm{Cp}_{3} \mathrm{UX}$ complexes was investigated in $\mathrm{THF}+\mathrm{NBu}_{4} \mathrm{PF}_{6}(0.1 \mathrm{M})$ electrolyte by cyclic voltammetry. Fig. 3 presents the typical electrochemical behaviour for these complexes in THF electrolyte at conventional microelectrode (a) and at ultramicroelectrode (b) illustrated with the case of the $\mathrm{Cp}_{3} \mathrm{UO}^{i} \mathrm{Pr}$ complex.

The different complexes were reduced according to a reversible one-electron transfer process. Half-wave potentials $\left(E_{1 / 2}\right)$ of reduction processes were determined from voltammograms obtained at conventional microelectrodes under pure diffusion condition from $\left(E \mathrm{p}_{\mathrm{c}}+E \mathrm{p}_{\mathrm{a}}\right) / 2$ and at ultramicroelectrode under steady state diffusion condition (with low potential scan rate: $50 \mathrm{mV} \mathrm{s}^{-1}$ ) from the potential at $i_{\text {lim }} / 2$. The $E_{1 / 2}$ values of the $\mathrm{U}(\mathrm{IV}) / \mathrm{U}(\mathrm{III})$ redox system given in the text correspond to the mean values of $E_{1 / 2}$ determinations (at least three experiments). ${ }^{34}$

We have already published the electrochemical studies of $\mathrm{Cp}_{3} \mathrm{UBH}_{4}{ }^{18}$ and $\mathrm{Cp}_{3} \mathrm{UCl}^{19}{ }^{19}$ In addition we have noticed that the complexes in the series studied here, present a redox system in oxidation corresponding to the oxidation of U(IV) to U(v) in the first stage of the process. Except for the oxidation of $\mathrm{Cp}_{3} \mathrm{UO}^{i} \mathrm{Pr}$, the $\mathrm{U}(\mathrm{v})$ complexes $\left[\mathrm{Cp}_{3} \mathrm{UX}\right]^{+}$formed at the electrode are not stable and the one-electron process is coupled with a disproportionation reaction as we have previously demonstrated. ${ }^{19}$ For $\mathrm{Cp}_{3} \mathrm{UO}^{i} \mathrm{Pr}$ we can see in Fig. 3(b) a different behaviour with a reversible $\mathrm{U}(\mathrm{IV}) / \mathrm{U}(\mathrm{v})$ oxidation process which indicates the stability of $\left[\mathrm{Cp}_{3} \mathrm{UO}^{i} \mathrm{Pr}\right]^{+}$during the time of the cyclic voltammetry.
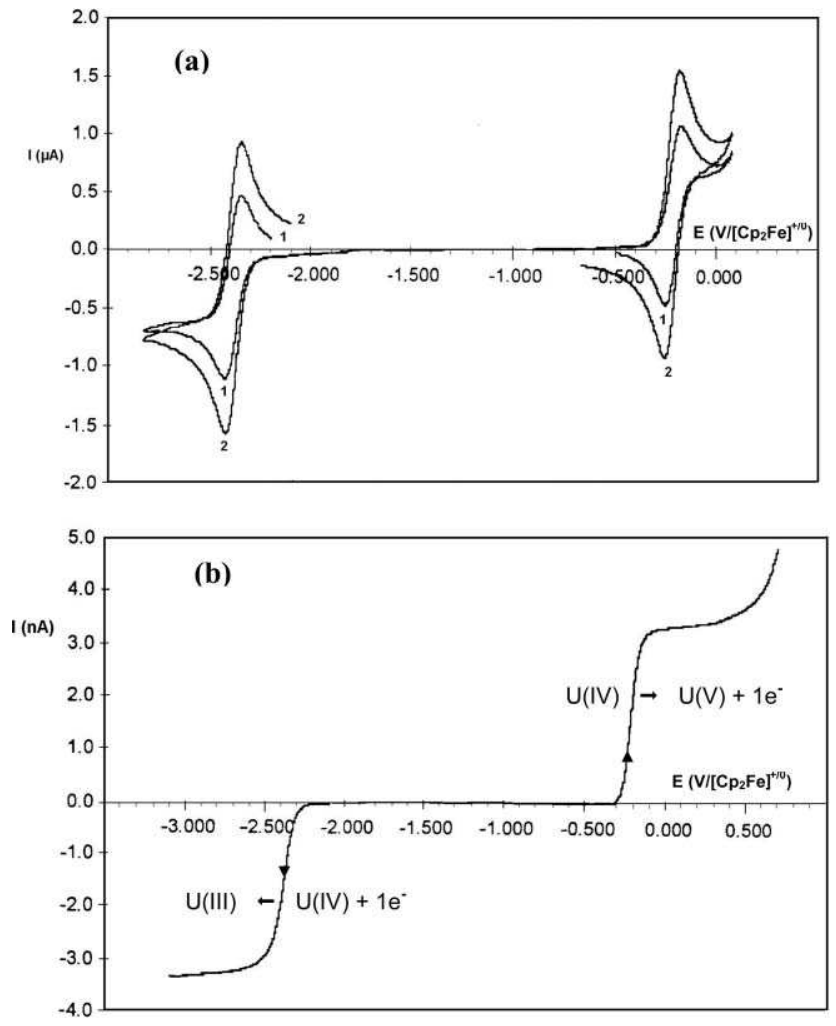

Fig. 3 Voltammograms of $1.30 \times 10^{-3} \mathrm{~mol} \mathrm{~L}^{-1} \mathrm{Cp}_{3} \mathrm{UO}^{i} \mathrm{Pr}$ in $0.11 \mathrm{~mol}$ $\mathrm{L}^{-1} \mathrm{Bu}_{4} \mathrm{NPF}_{6}+\mathrm{THF}$ (a) at conventional size disk platinum electrode $(\phi=1 \mathrm{~mm})$ for different scan rates (1) $0.01 \mathrm{~V} \mathrm{~s}^{-1}$ and (2) $0.025 \mathrm{~V}$ $\mathrm{s}^{-1} ; I R_{\mathrm{u}}$ correction $\left(R_{\mathrm{u}}=4000 \Omega\right) ; T=293 \mathrm{~K}$; (b) at platinum disk ultramicroelectrode $(\phi=15 \mu \mathrm{m})$ for $v=50 \mathrm{mV} \mathrm{s}^{-1}$.

Computational details. Determination of electron affinities is not an easy task. ${ }^{1}$ EA computations generally involve odd-electron systems where spin contamination and SCF convergence problems add to the difficulty of producing reliable results. Since available experimental molecular EAs are largely adiabatic, the most direct theoretical method is to calculate the difference of the energies of both the neutral and anionic forms of the complexes in their respective optimized geometries, i.e. the " $\Delta E$ method".

For our part, the calculations were performed using Density Functional Theory (DFT) ${ }^{35}$ with relativistic corrections being introduced via the Zero Order Regular Approximation (ZORA). ${ }^{36}$ Solvents effects have been taken into account using the Conductorlike Screening Model for Realistic Solvents (COSMO-RS). These ZORA/DFT calculations were performed using the Amsterdam Density Functional (ADF2007.01) program package. ${ }^{37}$ The Vosko-Wilk-Nusair functional (VWN) ${ }^{38}$ for the local density approximation (LDA) and the gradient corrections for exchange and correlation of Becke and Perdew, ${ }^{39}$ respectively, i.e. the BP86 functional, have been used. Triple- $\zeta$ Slater-type valence orbitals (STO) augmented by one set of polarization functions were used for all atoms. For all elements, the basis sets were taken from the ADF/ZORA/TZP database. The more extended ZORA/TZ2P basis set has also been used to check the accuracy of the computed properties. The frozen-core approximation where the core density is obtained from four-component Dirac-Slater calculations has been applied for all atoms. 1s core electrons were frozen respectively for boron $\mathrm{B}[1 \mathrm{~s}]$, carbon $\mathrm{C}[1 \mathrm{~s}]$ and oxygen $\mathrm{O}[1 \mathrm{~s}]$. 
For sulfur $\mathrm{S}[2 \mathrm{p}]$ and chlorine $\mathrm{Cl}[2 \mathrm{p}]$, the $1 \mathrm{~s} / 2 \mathrm{~s} / 2 \mathrm{p}$ cores were frozen. The U[5d] valence space of the heavy element includes the $5 \mathrm{f} / 6 \mathrm{~s} / 6 \mathrm{p} / 6 \mathrm{~d} / 7 \mathrm{~s} / 7 \mathrm{p}$ shells (14 valence electrons). Several studies have shown that such a ZORA/DFT/BP86/TZP approach reproduces the experimental geometries and ground states properties of f-block element compounds with a satisfying accuracy. ${ }^{40-44}$ In our case, we carried out first the full geometry optimizations of the species under consideration, in the gas phase, at the spin unrestricted level. Next, the geometries were reoptimized in the THF solvent using the COSMO model. We used the non-default Delley type of cavity, ${ }^{21 c}$ the solvent being considered with its dielectric constant of 7.58 and a radius of $3.18 \AA$. Then, single point calculations including spin-orbit corrections were carried out using the previously optimized geometries, for both the gas phase and the solution.

Molecular geometries and molecular orbital plots were generated by using the MOLEKEL $4.3^{45}$ and the ADFVIEW ${ }^{37 c}$ programs, respectively.

\section{Acknowledgements}

We thank Jean-Claude Berthet of the Service de Chimie Moléculaire (CEA/Saclay) for the synthesis of the studied complexes. We also thank the French and Algerian governments for the research grant CMEP 07 MDU 700.

\section{References}

1 J. C. Rienstra-Kiracofe, G. S. Tschumper, H. F. Schaefer, S. Nandi and G. B. Ellison, Chem. Rev., 2002, 102, 231.

2 (a) C. J. Burns and M. S. Eisen, in The Chemistry of the Actinide and Transactinide Elements, ed. L. R. Morss, N. Edelstein, J. Fuger and J. J. Katz, Springer, Dordrecht, The Netherlands, 3rd edn, 2006, vol. 5, ch. 25, pp. 2799; (b) M. Ephritikhine, Dalton Trans., 2006, 2501.

3 L. T. Reynolds and G. Wilkinson, J. Inorg. Nucl. Chem., 1956, 2, 246.

4 B. Kanellakopulos, E. O. Fischer, E. Dornberger and F. Baumgartner, J. Organomet. Chem., 1970, 24, 507.

5 P. J. Fagan, J. M. Manriquez, E. A. Maatta, A. M. Seyam and T. J. Marks, J. Am. Chem. Soc., 1981, 103, 6650.

6 T. Mehdoui, J. C. Berthet, P. Thuéry, L. Salmon, E. Rivière and M. Ephritikhine, Chem.-Eur. J., 2005, 11, 6994.

7 (a) W. J. Evans, G. W. Nyce, K. J. Forrestal and J. W. Ziller, Organometallics, 2002, 21, 1050; (b) W. J. Evans, S. A. Kozimor and J. W. Ziller, Chem. Commun., 2005, 4681; (c) W. J. Evans, G. W. Nyce and J. W. Ziller, Angew. Chem., Int. Ed., 2000, 39, 240; (d) W. J. Evans, S. A. Kozimor, J. W. Ziller and N. Kaltsoyannis, J. Am. Chem. Soc., 2004, 126, 14533.

8 (a) J. Maynadié, J. C. Berthet, P. Thuéry and M. Ephritikhine, J. Am. Chem. Soc., 2006, 128, 1082; (b) J. Maynadié, J. C. Berthet, P. Thuéry and M. Ephritikhine, Organometallics, 2006, 25, 5603; (c) J. Maynadié, N. Barros, J. C. Berthet, P. Thuéry, L. Maron and M. Ephritikhine, Angew. Chem., Int. Ed., 2007, 46, 2010.

9 P. B. Duval, C. J. Burns, D. L. Clark, D. E. Morris, B. L. Scott, J. D. Thompson, E. L. Werkema, L. Jia and R. A. Andersen, Angew. Chem., Int. Ed., 2001, 40, 358.

10 J. L. Kiplinger, D. E. Morris, B. L. Scott and C. J. Burns, Chem. Commun., 2002, 30.

11 J. Maynadié, J. C. Berthet, P. Thuéry and M. Ephritikhine, Chem. Commun., 2007, 486.

12 (a) D. E. Morris, R. E. Da Re, K. C. Jantunen, I. Castro-Rodriguez and J. L. Kiplinger, Organometallics, 2004, 23, 5142; (b) E. J. Schelter, P. Yang, B. L. Scott, J. D. Thomson, R. L. Martin, P. J. Hay, D. E. Morris and J. L. Kiplinger, Inorg. Chem., 2007, 546, 7477.

13 R. G. Finke, G. Gaughan and R. Voegeli, J. Organomet. Chem., 1982, 229, 179.
14 Y. Mugnier, A. Dormond and E. Laviron, J. Chem. Soc., Chem. Commun., 1982, 257.

15 F. Ossola, P. Zanella, P. Ugo and R. Seeber, Inorg. Chim. Acta, 1988, $147,123$.

16 D. C. Sonnenberger and J. G. Gaudiello, Inorg. Chem., 1988, 27, 2747.

17 D. Hauchard, M. Cassir, J. Chivot and M. Ephritikhine, J. Electroanal. Chem., 1991, 313, 227.

18 D. Hauchard, M. Cassir, J. Chivot, D. Baudry and M. Ephritikhine, $J$. Electroanal. Chem., 1993, 347, 399.

19 C. Clappe, D. Leveugle, D. Hauchard and G. Durand, J. Electroanal. Chem., 1998, 448, 95.

20 R. Schnabel, B. Scott, W. Smith and C. Burns, J. Organomet. Chem., 1999, 591, 14.

21 (a) A. Klamt and G. Schüürmann, J. Chem. Soc., Perkin Trans. 2, 1993, 799; (b) A. Klamt, J. Phys. Chem., 1995, 99, 2224; (c) A. Klamt and V. Jones, J. Chem. Phys., 1996, 105, 9972; (d) A. Klamt, V. Jonas, T. Bürger and J. C. Lohrenz, J. Phys. Chem. A, 1998, 102, 5074; (e) B. Delley, Mol. Simul., 2006, 32, 117; (f) A. Klamt, COSMO-RS From Quantum Chemistry to Fluid Phase Thermodynamics and Drug Design, Elsevier, Amsterdam, The Netherlands, 2005, ISBN 0-444-51994-7.

22 C. H. Wong, T. Yen and T. Lee, Acta Crystallogr., Sect. C, 1965, 18, 340.

23 P. Zanella, N. Brianese, U. Casellato, F. Ossola, M. Porchia, G. Rossetto and R. Graziani, Inorg. Chim. Acta, 1988, 144, 129.

24 P. C. Leverd, M. Ephritikhine, M. Lance, J. Vigner and M. Nierlich, J. Organomet. Chem., 1996, 507, 229.

25 M. Porchia, N. Brianese, U. Casellato, F. Ossola, G. Rossetto, P. Zanella and R. Graziani, J. Chem. Soc., Dalton Trans., 1989, 677.

26 M. R. Spirlet, J. Rebizant, C. Apostolidis, G. Van den Bossche and B. Kanellakopulos, Acta Crystallogr., Sect. C, 1990, 46, 2318.

27 R. D. Shannon, Acta Crystallogr., Sect. A, 1976, 32, 751.

28 C. Lescop, T. Arliguie, M. Lance, M. Nierlich and M. Ephritikhine, J. Organomet. Chem., 1999, 580, 137.

29 T. Arliguie, C. Lescop, L. Ventelon, P. C. Leverd, P. Thuéry, M. Nierlich and M. Ephritikhine, Organometallics, 2001, 20, 3698.

30 I. Mayer, Chem. Phys. Lett., 1983, 97, 270.

31 A. J. Bridgeman, G. Cavigliasso, I. Ireland and J. Rothery, J. Chem. Soc., Dalton Trans., 2001, 2095.

32 M. L. Anderson and L. R. Crisler, J. Organomet. Chem., 1969, 17, 345.

33 B. Delavaux-Nicot and M. Ephritikhine, J. Organomet. Chem., 1990, 399, 77.

34 C. Clappe, D. Sc. Thesis, Université de Paris VI, 1997.

35 (a) P. Hohenberg and W. Kohn, Phys. Rev., 1964, 136, B864; (b) W. Kohn and L. J. Sham, Phys. Rev., 1965, 140, A1133; (c) R. G. Parr and W. Yang, Density-Functional Theory of Atoms and Molecules, Oxford University Press, UK, 1989.

36 (a) E. van Lenthe, E. J. Baerends and J. G. Snijders, J. Chem. Phys., 1993, 99, 4597; (b) E. van Lenthe, E. J. Baerends and J. G. Snijders, J. Chem. Phys., 1994, 101, 9783; (c) E. van Lenthe, A. Ehlers and E. J. Baerends, J. Chem. Phys., 1999, 110, 8943.

37 (a) G. C. Fonseca, J. G. Snijders, G. te Velde and E. J. Baerends, Theor. Chem. Acc., 1998, 391; (b) G. te Velde, F. M. Bickelhaupt, S. A. J. van Gisbergen, G. C. Fonseca, E. J. Baerends, J. G. Snijders and T. Ziegler, J. Comput. Chem., 2001, 931; (c) ADF2007.01, SCM, Theoretical Chemistry, Vrije University, Amsterdam, The Netherlands, http://www.scm.com.

38 S. D. Vosko, L. Wilk and M. Nusair, Can. J. Chem., 1990, 58, 1200.

39 (a) A. D. Becke, Phys. Rev. A, 1988, 38, 3098; (b) J. P. Perdew, Phys. Rev. B, 1986, 34, 7406.

40 G. Ricciardi, A. Rosa, E. J. Baerends and S. A. J. van Gisbergen, J. Am. Chem. Soc., 2002, 124, 1233.

41 N. Kaltsoyannis, Chem. Soc. Rev., 2003, 32, 9.

42 M. Roger, L. Belkhiri, P. Thuéry, T. Arliguie, M. Fourmigué, A. Boucekkine and M. Ephritikhine, Organometallics, 2005, 24, 4940.

43 L. Belkhiri, R. Lissillour and A. Boucekkine, J. Mol. Struct. (Theochem), 2005, 757, 155.

44 M. Benyahia, L. Belkhiri and A. Boucekkine, J. Mol. Struct. (Theochem), 2006, 777, 61.

45 MOLEKEL4.3, P. Flükiger, H. P. Lüthi, S. Portmann and J. Weber, Swiss Center for Scientific Computing, Manno, Switzerland, 2000, http://www.cscs.ch. 